\title{
Mineralogical controls on the Ti isotope composition of subduction zone magmas
}

\author{
SEBASTIAN KOMMESCHER ${ }^{1}$, FLORIAN KURZWEIL ${ }^{2}$, \\ RAÚL O.C. FONSECA ${ }^{1}$, LAURA JENNIFER ANABEL \\ RZEHAK $^{3}$, PETER SPRUNG ${ }^{4}$ AND CARSTEN MÜNKER ${ }^{2}$ \\ ${ }^{1}$ Ruhr-University Bochum \\ ${ }^{2}$ University of Cologne \\ ${ }^{3}$ Ruhr Universität Bochum \\ ${ }^{4}$ Paul Scherrer Institut \\ Presenting Author: s.kommescher@mineralogie.uni-hannover.de
}

Reconstructing petrogenetic processes during magma genesis in subduction zone settings mainly relies on trace element abundance patterns or radiogenic and stable isotope data obtained from igneous rock samples. Mass-dependent Ti isotope variations are an emerging geochemical tool used to characterise the evolution of igneous rock suites ${ }^{[1]}$. In particular, it has been noted that the titanium isotope composition $\left(\delta^{49} \mathrm{Ti}\right)$ of igneous rock samples becomes isotopically heavier with increasing $\mathrm{SiO}_{2}$ content, due to the continuous fractional crystallisation of Ti-rich oxide minerals ${ }^{[1,2,3]}$. However, some variations in the $\delta^{49} \mathrm{Ti}$ of subduction-related igneous rocks may indicate that mineral phases other than oxides may also affect the value of $\delta^{49} \mathrm{Ti}$ in subduction-related lithologies.

We present $\delta^{49} \mathrm{Ti}$ values for a representative set of subductionrelated basalts, andesites, and boninites. Samples from the Solomon Islands, the UPL from the Troodos ophiolite (Cyprus), and Cape Vogel (Papua New Guinea) show little variability in $\delta^{49} \mathrm{Ti}\left(-0.027\right.$ to $+0.111 \%$ o). Small but resolvable $\delta^{49} \mathrm{Ti}$ variations among these samples are likely related to the residual mineral assemblages of their mantle sources. For example, the slightly higher $\delta^{49} \mathrm{Ti}$ of boninites $(+0.109$ to $+0.168 \%$ ) compared to tholeiites $(-0.027$ to $+0.111 \%$ ) from the same localities could result from partial melting of a depleted harzburgitic source with residual $\mathrm{Cr}$-spinel controlling the Ti budget. A more pronounced variation in $\delta^{49} \mathrm{Ti}$ is clearly linked to the fractional crystallisation of Ti-rich minerals (Sunda arc in Indonesia and New Britain in Papua New Guinea). A co-genetic differentiation suite from the Rabaul caldera in New Britain shows increasing $\delta^{49} \mathrm{Ti}$ (up to $+0.373 \%$ ) with increasing $\mathrm{V}$ content and decreasing $\mathrm{Dy} / \mathrm{Yb}$, which we interpret to result from combined fractional crystallization of magnetite and amphibole. This hypothesis is supported by petrogenetic modelling, which suggests that the crystallisation of both magnetite and amphibole increase the $\delta^{49} \mathrm{Ti}$ of the melt.

[1] Millet et al., (2016) EPSL, 449, 197-205; [2] Hoare et al., (2020) GCA, 282, 38-54; [3] Zhao et al., (2020) Contrib. to Mineral. Petrol., 175, 67. 